\title{
The anticancer activity of dichloromethane crude extract obtained from Calea pinnatifida
}

\author{
This article was published in the following Dove Press journal: \\ Journal of Experimental Pharmacology \\ 17 November 2012 \\ Number of times this article has been viewed
}

\author{
Gabriela M Marchetti ${ }^{1,2}$ \\ Karina A Silva ${ }^{3}$ \\ Arianny N Santos ${ }^{3}$ \\ Ilza MO Sousa ${ }^{3}$ \\ Sirlene V Tinti ${ }^{2}$ \\ Glyn M Figueira ${ }^{4}$ \\ Mary A Foglio 1,3 \\ João E Carvalho',2 \\ 'Programa de Pós Graduação \\ em Biologia Celular e Estrutural, \\ Institute of Biology, ${ }^{2}$ Pharmacology \\ and Toxicology Department. \\ Multidisciplinary Center \\ for Chemical, Biological and \\ Agricultural Research (CPQBA), \\ ${ }^{3}$ Phytochemistry Department, CPQBA, \\ ${ }^{4}$ Agrotechnology Department, \\ CPQBA, University of Campinas - \\ UNICAMP, Campinas, Brazil
}

\begin{abstract}
The genus Calea is reported for many biological activities such as antiinflammatory, antiplasmodial, antifungal, antimicrobial, and cytotoxic activities. Most of the pharmacological activities are credited to germacranolides, a sesquiterpene lactone common to this genus. Dried aerial parts of Calea pinnatifida Banks were extracted with dichloromethane, which generated the dichloromethane crude extract (DCE). The main purpose of this study was to evaluate the anticancer activity of DCE performed in sulforhodamine B cytotoxicity in vitro assay against human cancer cell lines and in vivo Ehrlich models. The DCE showed a high potency and selectivity for the melanoma and kidney cell line. Two in vivo assays were also conducted in the Ehrlich ascites tumor and Ehrlich solid tumor. In the Ehrlich ascites tumor assay, the treatment with DCE increased survival rates at the highest dose $(200 \mathrm{mg} / \mathrm{kg})$. Interestingly, in the Ehrlich solid tumor, by increasing the number of treatments from one to three times a week, the tumor growth was inhibited by a lower dose $(100 \mathrm{mg} / \mathrm{kg})$. These results encouraged follow-up studies with $C$. pinnatifida in order to identify the active principles and to determine the anticancer mechanism of action.
\end{abstract}

Keywords: Calea pinnatifida, cytotoxicity, cancer, Ehrlich ascitic tumor, Ehrlich solid tumor

\section{Introduction}

Plants have served as a rich source of therapeutic agents for many centuries, being used themselves or as the basis for synthetic drugs. Despite the great developments in organic synthesis, $55 \%$ of recent chemotherapeutic drugs are derived from or based upon natural products. ${ }^{1}$ The use of plants as food and in folk and traditional medicine has led to their being one of the main agents in the research and development of cancer chemopreventive drugs. ${ }^{2,3}$

Calea pinnatifida Banks is used in folk medicine in the treatment of stomach ache, giardiasis, and amoebiasis. ${ }^{4}$ Belonging to the Asteraceae family, extracts from the leaves of this plant are composed chiefly of fatty esters, 4-glycosyloxybenzoic acid, anisic acid, sitosterol, stigmasterol, polyacetilene, and germacranolides. ${ }^{5}$

The genus Calea has approximately 110 species. It is found in tropical and subtropical regions, and contains germacranolides as a common chemical component. ${ }^{4-6}$ Many biological activities, including antiinflammatory, antiplasmodial, antileishmanial, acaricidal, antifungal, antimicrobial, and cytotoxic, have been reported for this genus. ${ }^{6-12}$ Germacranolides have also been reported to have other properties such as the ability to induce apoptosis, cytotoxicity, antifungal activity, and inhibitory activity against $\mathrm{NF}-\kappa \mathrm{B} .{ }^{6,10-14}$

\footnotetext{
Correspondence: João Ernesto de Carvalho

Pharmacology and Toxicology Department, Centro Pluridisciplinar de Pesquisas Químicas, Biológicas e Agrícolas (CPQBA), PO BOX 617I, Campinas, SP, Brazil

Tel +55 1921392876

Fax +55 1921392852

Email carvalho@cpqba.unicamp.br
} 
Arucanolide, a germacranolide isolated from C. urticifolia, induced apoptosis in HL60 cells by dissipating the mitochondrial membrane potential, and triggering apoptosis-inducing factor..$^{15}$ Among the compounds identified in C. pinnatifida, the germacranolides seem to be the most relevant substances, as they promote many biological activities in the potential development of anticancer agents. ${ }^{10-14}$

Since previous literature has not examined C. pinnatifida and its anticancer-related influences, the aim of the present study is to examine the antitumor activity of the crude extract taken from this species in both in vitro and in vivo assays.

\section{Materials and methods}

\section{Plant material}

The aerial components of $C$. pinnatifida Banks were collected in wildcrafting and identified at the Multidisciplinary Center for Chemical, Biological, and Agricultural Research (CPQBA, University of Campinas, São Paulo, Brazil). A voucher specimen, which was positively identified by MSc Katia Calago Althoff, botanist, was deposited at the CPQBA Herbarium (Number 107).

\section{Obtaining dichlomethane and ethanolic crude extract (DCE and ECE)}

Dried aerial parts of $C$. pinnatifida were ground prior to use in a Stephen mill (model UM 40), and an aliquot (300 g) was extracted by soxhlet (1000 mL; $2 \times 48$ hours) with dichloromethane (Merck ${ }^{\circledR}$ KGaA, Darmstadt, Germany). This provided the dichloromethane crude extract (DCE) after solvent evaporation. The plant residue was extracted with ethanol $96^{\circ} \mathrm{GL}\left(\mathrm{Merck}^{\circledR}\right)$ in the same conditions cited above. The solvent was evaporated at $45^{\circ} \mathrm{C}$ under vacuum, and it was subsequently lyophilized, resulting in ethanolic crude extract (ECE).

\section{In vitro anticancer activity assay}

Human tumor cell lines, UACC-62 (melanoma), MCF-7 (breast), NCI-ADR/RES (resistant ovary), 786-O (kidney), NCI-H460 (lung, non-small cell), PC-3 (prostate), OVCAR-3 (ovary), HT29 (colon), and K-562 (leukemia), were kindly provided by the US National Cancer Institute. Stock cultures were grown in medium containing $5 \mathrm{~mL}$ RPMI $1640\left(\mathrm{Gibco}^{{ }^{\circledR}}\right.$ BRL; Life Technologies, Carlsbad, CA) supplemented with $5 \%$ fetal bovine serum. Gentamicine $(50 \mu \mathrm{g} / \mathrm{mL})$ was added to the experimental cultures. Cells in 96-well plates (plates: $100 \mu \mathrm{L}$ cells/well; inoculation density ranging from 4 to $7 \times 10^{4}$ cells $/ \mathrm{mL}$ ) were exposed to sample concentrations in DMSO/RPMI $(0.25,2.5,25$, and $250 \mu \mathrm{g} / \mathrm{mL})$ at $37^{\circ} \mathrm{C}$, with
$5 \% \mathrm{CO}_{2}$ in air for 48 hours. The final DMSO concentration did not affect cell viability. Following this preparation, cells were fixed with $50 \%$ trichloroacetic acid, and cell proliferation was determined by spectrophotometric quantification $(540 \mathrm{~nm})$ of cellular protein content using sulforhodamine B assay. ${ }^{16,17}$ Doxorubicin (doxorubicin chloridrate, $50 \mathrm{mg}$; $11 \%$ purity; Eurofarma, São Paulo, Brazil) was adopted as a positive control. Using the concentration response curve for each cell line, total growth inhibition (TGI) was determined through nonlinear regression analysis (Table 1) using ORIGIN 8.0 software (OriginLab Corporation, Northampton, MA). ${ }^{18-20}$

\section{In vivo assay - acute toxicity}

$\mathrm{BALB} / \mathrm{c}$ mice were treated intraperitoneally (IP) with DCE at doses of 100, 300, 500, and $1000 \mathrm{mg} / \mathrm{kg}$. Groups were observed during 4 hours and then daily for 14 days. The following general toxicity parameters were evaluated: body weight loss, locomotion, behavior (agitation, lethargy), respiration, salivation, tearing eyes, cyanosis, and mortality. ${ }^{21,22}$ The lethal dose was calculated by linear regression, as described by Litchfield and Wilcoxon. ${ }^{22}$

\section{In vivo assay - Ehrlich tumor}

DCE was evaluated in vivo on an Ehrlich ascitic tumor (EAT) and Ehrlich solid tumor (EAT) assay. Ehrlich tumor cells were maintained in the ascites form by peritoneal passages in mice via weekly transplantation of $5 \times 10^{5}$ tumor cells. Male BALB/c mice aged $8-10$ weeks and weighing 25-30 g were used for Ehrlich tumor experiments. The animals were obtained from the Multidisciplinary Center for Biological Investigation on Laboratory Animal Science-UNICAMP, and were maintained under controlled temperature conditions $\left(22^{\circ} \mathrm{C}-24^{\circ} \mathrm{C}\right)$, light $(12$ hours of light, 12 hours of dark) and humidity (45\%-65\%), with

Table I Comparative TGI $(\mu \mathrm{g} / \mathrm{mL})$ in human tumor cell lines

\begin{tabular}{llll}
\hline Cell lines & Doxorubicin & DCE & ECE \\
\hline UACC-62 & 0.04 & 13.77 & $>250$ \\
MCF-7 & 0.69 & 204.85 & $>250$ \\
NCI-ADR/RES & 5.53 & 228.58 & $>250$ \\
786-O & 0.79 & 8.41 & $>250$ \\
NCI-H460 & 0.05 & 44.22 & $>250$ \\
PC-3 & 0.87 & 24.35 & $>250$ \\
OVCAR-3 & 4.32 & 28.08 & $>250$ \\
HT-29 & 0.02 & 50.45 & 80.0 \\
K-562 & 2.45 & $>250$ & $>250$ \\
\hline
\end{tabular}

Abbreviations: TGI, total growth inhibition; DCE, dichloromethane crude extract; $\mathrm{ECE}$, ethanolic crude extract. 
food and water ad libitum. All procedures were conducted in accordance with the principles and guidelines adopted by the Institutional Committee for Ethics in Animal Research at the University of Campinas (CEEA, UNICAMP, protocol 1421-1, December 19, 2007).

\section{Ehrlich ascites assay}

Ehrlich tumor cells $\left(1.0 \times 10^{4}\right)$ were implanted IP, and the animals $(n=10)$ were treated with the samples, IP, once a week over the course of 21 days; the animals were followed for a total of 90 days. The animals were divided into three groups: negative control group (vehicle); positive control group (doxorubicin chloridrate, $50 \mathrm{mg}$; $11 \%$ purity) at a dose of $3.0 \mathrm{mg} / \mathrm{kg}$; and DCE treated groups. DCE was administered at doses of 50, 100, and $200 \mathrm{mg} / \mathrm{kg}$. Anticancer activity was assessed by the survival rates of the groups. ${ }^{3,23}$

\section{Ehrlich solid assay}

Ehrlich tumor cells $\left(1.0 \times 10^{5}\right)$ were implanted subcutaneously in the region of the back, and the animals $(n=8)$ were treated with the samples, IP, every 48 hours over the course of 15 days. The animals were divided into groups: negative control group (vehicle); positive control group (doxorubicin chloridrate, $50 \mathrm{mg} ; 11 \%$ purity) at a dose of $3.0 \mathrm{mg} / \mathrm{kg}$; and DCE treated groups. DCE was administered at doses of 50 and $100 \mathrm{mg} / \mathrm{kg}$. The tumor volume was measured using a pachymeter (height $\times$ width $\times$ length). Anticancer activity was assessed by comparing the relative tumor weight (tumor weight/ animal weight) and tumor volume using the equation:

(Mean [Relative Tumor Weight or Volume] of the Negative Control Group - Mean [Relative Tumor Weight or Volume] of Treatment Groups)/Mean (Relative Tumor Weight or Volume) of the Negative Control Group $\times 100 .^{3}$

\section{Statistical analyses}

Results are expressed as the mean \pm standard deviation (SD) per group. Statistical evaluation was done using analysis of variance, followed by Duncan's new multiple range test using StatSoft ${ }^{\circledR}$ software (StatSoft, Inc, Tulsa, OK). Graphics were designed using the ORIGIN ${ }^{\circledR}$ software. Differences were considered significant at $P \leq 0.05$ and are represented by asterisks $\left(* P<0.05,{ }^{*} * P<0.01, * * * P<0.001\right)$.

\section{Results}

The evaluation of DCE in the in vitro sulforhodamine B assay demonstrated that this extract has a strong relationship between its concentration and the effect on and selectivity for the melanoma (UACC-62) and kidney (786-O) cell lines.

The TGI shown in Table 1 demonstrated the activity of DCE, ECE, and doxorubicin. DCE is very potent and kills all cell lines; meanwhile, the ECE did not show any antiproliferative effects. Doxorubicin shows high cytotoxic activity in almost all cell lines except for NCI-ADR/RES, which expresses a multidrug resistance phenotype.

Subsequently, the DCE was selected for in vivo studies. Through IP administration, DCE showed a 50\% lethal dose of $500 \mathrm{mg} / \mathrm{kg}$ in an acute toxicity test. The IP route was chosen because the absorption barriers are similar to the intravenous route, which more closely resembles current clinical applications for chemotherapy treatment. The results of this toxicity study established the doses used for in vivo assays. ${ }^{22}$

The in vivo EAT anticancer activity was determined by the survival life span by comparing the mortality rate of the treatment groups versus the control group (Figure 1). Only the highest dose $(200 \mathrm{mg} / \mathrm{kg})$ increased the survival rate when compared with the negative control group $(P=0.009)$. In spite of the antitumor activity, the $200 \mathrm{mg} / \mathrm{kg}$ dose caused the death of one experimental animal before the negative control group; therefore, the dose had no relationship with tumor development. Both the $50 \mathrm{mg} / \mathrm{kg}$ and the $100 \mathrm{mg} / \mathrm{kg}$ doses did not show any anticancer activity in this assay using once a week treatment, and the positive control (doxorubicin) increased the overall survival time, demonstrating antitumor activity, as expected $(P<0.001)$.

In vivo EST anticancer activity was determined by the reduction of the relative tumor weight and tumor volume. In this assay, $100 \mathrm{mg} / \mathrm{kg}$ of DCE showed anticancer activity in a treatment that was administered every 48 hours. This dose inhibited $66.7 \%$ of the relative tumor weight $(P=0.0002)$

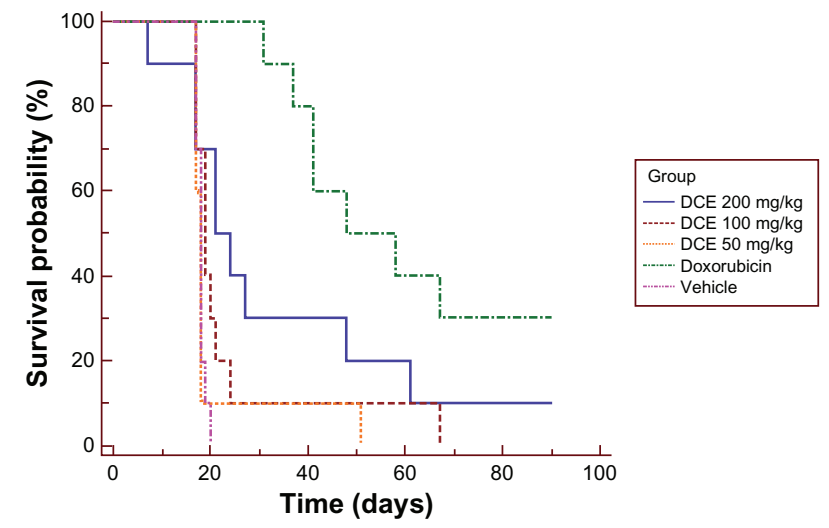

Figure I Kaplan-Meier survival curves of mice treated with Calea pinnatifida DCE. Notes: Doses of $50 \mathrm{mg} / \mathrm{kg}(P-0.973), 100 \mathrm{mg} / \mathrm{kg}(P=0.202)$, and $200 \mathrm{mg} / \mathrm{kg}$ $(P=0.009)$. Controls: vehicle (negative) and doxorubicin (positive) $(P<0.00 \mathrm{l})$. Abbreviation: DCE, dichloromethane crude extract. 
and $57.6 \%$ of tumor volume $(P=0.012)$, whereas the $50 \mathrm{mg} / \mathrm{kg}$ dose increased the tumor weight $(P=0.004)$, but did not show any differences in the volume from negative control $(P=0.06)$. The positive control (doxorubicin) inhibited $71.6 \%$ of the tumor weight $(P=0.0007)$ and $66.5 \%$ of tumor volume $(P=0.032)$ (Figure 2$)$.

\section{Discussion}

Because of the high number of cancer cases, the interest in alternative therapies using natural products are increasing, especially those derived from plants. ${ }^{24,25}$ In order to look for new sources of therapeutic anticancer agents, many plant extracts and active principles have been studied in in vitro and in vivo cancer models, and the correlation of both studies became one of the key steps for the success of this type of research. ${ }^{1}$

Since the knowledge that different cell lines display varying sensitivities towards cytotoxic compounds, the use of more than one cell line is considered necessary for the detection of anticancer compounds. ${ }^{21}$ Bearing this in mind, cell lines of different histological origins were used in the present study. An in vivo model could potentially broaden these results, but more data needs to be compiled prior to this being a viable option to overpass the limitations of the in vitro models. ${ }^{26}$

Previous studies demonstrated that other Calea species have many different biological properties, such as cytotoxicity and antiinflammatory activities. ${ }^{6,7}$ However, the present study showed, for the first time, the antitumor activity of $C$. pinnatifida crude extract, both in in vitro and in vivo experimental models. The DCE inhibited cell growth at low concentrations ranging from 8.0 to $70.0 \mu \mathrm{g} / \mathrm{mL}$

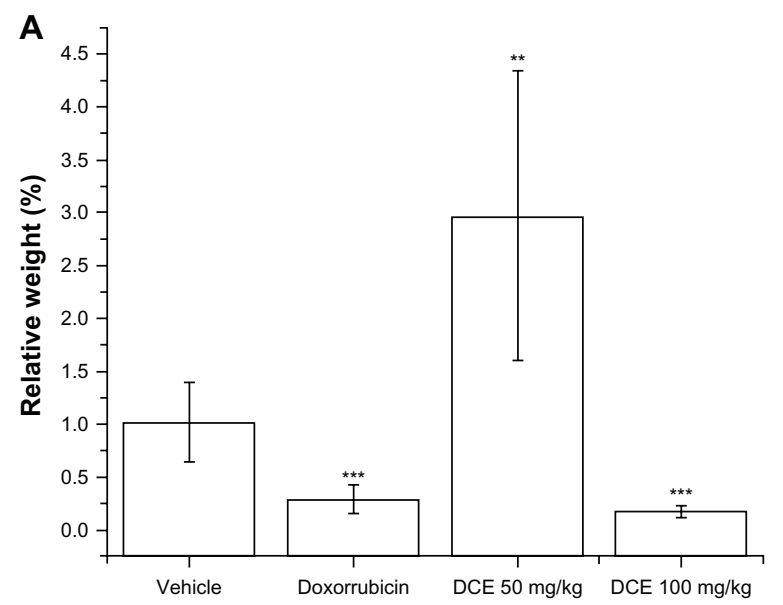

(TGI value) with highest selectivity noted for kidney (786-O) and melanoma (UACC-62) cell lines with TGI of 8.41 and $13.77 \mu \mathrm{g} / \mathrm{mL}$, respectively (Table 1 ). These data were used as the determining point to study the activity of DCE in a murine cancer model.

In the EAT model, the $C$. pinnatifida DCE antitumoral activity was confirmed by the prolongation of the life-span in once-a-week treated groups at the dose of $200 \mathrm{mg} / \mathrm{kg}$. These results are important since the EAT is a very aggressive tumor, ${ }^{27}$ killing the negative control group after 20 days of tumor cells inoculation. The EAT implantation induced a local inflammatory reaction, increasing vascular permeability and resulting in cellular migration and progressive ascites fluid formation. ${ }^{23}$ The ascites fluid formation is essential for tumor growth, as this constitutes the direct nutritional source for tumor cells. ${ }^{3,28}$ Since the extract increased animal survival, these findings suggest either a direct cytotoxic effect on tumor cells, as previously observed in vitro, or an indirect local effect provided by an antiinflammatory activity as described by other species of the genus Calea. ${ }^{3,5,29}$

To investigate whether the inhibitory effect of C. pinnatifida on Ehrlich tumors would be local or systemic, we evaluated the effect of IP treatment in another cancer model, the EST. In order to avoid the acute toxicity observed in the EAT model at a dose of $200 \mathrm{mg} / \mathrm{kg}$, we increased the frequency of dosing and reduced the maximum dose administrated. The smaller interval between treatments proved to yield better anticancer activity since $100 \mathrm{mg} / \mathrm{kg}$ was able to diminish the tumor size in EST, whereas the same dose did not increase the survival rate in the EAT model. The possible explanation for these results may be the maintenance

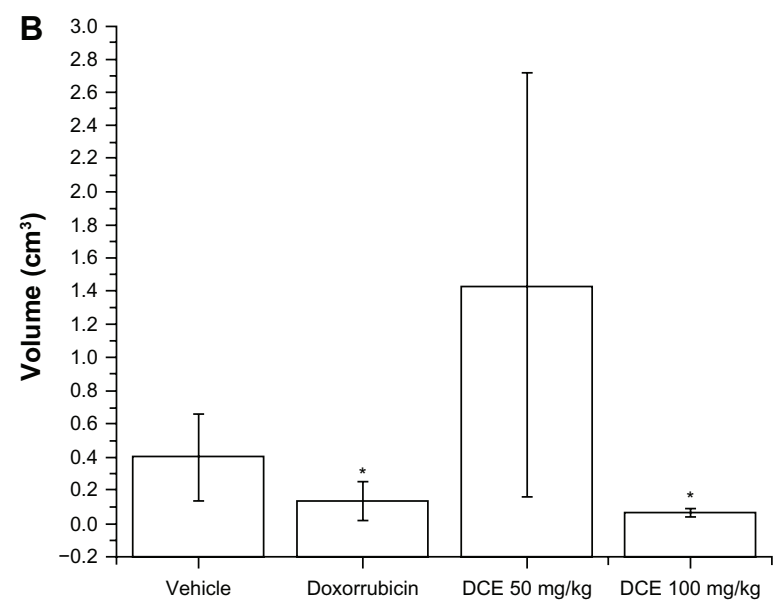

Figure 2 Ehrlich solid relative tumor weight and tumor volume of mice treated with Calea pinnatifida DCE. Ehrlich solid relative tumor weight (A) and tumor volume (B) of mice treated with C. pinnatifida DCE.

Notes: Doses of $50 \mathrm{mg} / \mathrm{kg}$ and $100 \mathrm{mg} / \mathrm{kg}$. Controls: vehicle (negative) and doxorubicin (positive). $* P<0.5$; **P $<0.01$; ***P $<0.00 \mathrm{I}$.

Abbreviation: DCE, dichloromethane crude extract. 
of DCE blood levels in an every-two-day schedule rather than a once-a-week treatment schedule, when using the same dose level. However, further pharmacokinetics studies are required to determine the half-life of DCE.

Despite the anticancer activity of the DCE at $100 \mathrm{mg} / \mathrm{kg}$, the dose of $50 \mathrm{mg} / \mathrm{kg}$ increased tumor weight, demonstrating that the use of the DCE in cancer treatment should be carefully reviewed with more assays to understand the molecular mechanisms involved in this activity, as well as to identify the active principles with proinflammatory and protumorigenic activity. Although there are not enough data to draw strong conclusions, these results present a systemic effect of the DCE by both reducing the solid subcutaneous tumor, as well as increasing the survival rate in the ascitic model.

All the substances involved in the antitumor effect of C. pinnatifida DCE are unknown, even though some compounds found in the extract such as the germacranolides could explain these results. ${ }^{4}$ These compounds have been described as potent apoptosis inductors, as well as inhibitors of NF- $\kappa \mathrm{B}$, an important immune and inflammatory response mediator. ${ }^{11,12,15}$ The induction of apoptosis and immunomodulatory activity are important mechanisms for some cancer treatments. ${ }^{30}$

Both in vitro and in vivo anticancer activity observed in the present study stimulate future research using the DCE obtained from $C$. pinnatifida as a chemotherapeutic agent. Additional phytochemical studies are in progress to identify the active principles involved in this antitumor activity.

\section{Acknowledgments}

The authors are grateful for the technical support offered by Benício Pereira from the Division of Agrotecnology-CPQBA/ UNICAMP and to Adilson Sartoratto from the Division of Organic and Pharmaceutical Chemistry - CPQBA/ UNICAMP. The authors also thank FAPESP (2008/53652-7), $\mathrm{CNPq}$, and Capes for their financial support.

\section{Disclosure}

The authors report no conflicts of interest in this work.

\section{References}

1. Newman DJ, Cragg GM. Natural products as sources of new drugs over the 30 years from 1981 to 2010. J Nat Prod. 2012;75(3):311-335.

2. Cragg GM, Newman DJ. Nature: a vital source of leads for anticancer drug development. Phytochem Rev. 2009;8(2):313-331.

3. Nascimento FR, Cruz GV, Pereira PV, et al. Ascitic and solid Ehrlich tumor inhibition by Chenopodium ambrosioides L. treatment. Life Sci. 2006;78(22):2650-2653.

4. Pruski JF, Urbatsch LE. Five new species of Calea (Compositae: Heliantheae) from planaltine Brazil. Brittonia. 1988;40(4):341-356.
5. Ferreira ZS, Roque NF, Gottlieb OR, Oliveira F, Gottlieb HE. Structural clarification of germacranolides from Calea species. Phytochemistry. 1980;19(7):1481-1484.

6. Yamada M, Matsuura N, Suzuki H, et al. Germacranolides from Calea urticifolia. Phytochemistry. 2004;65(23):3107-3111.

7. Venegas-Flores H, Segura-Cobos D, Vázquez-Cruz B. Antiinflamatory activity of the aqueous extract of Calea zacatechichi. Proc West Pharmacol Soc. 2002;45:110-111.

8. do Nascimento AM, Salvador MJ, Candido RC, Ito IY, de Oliveira DC. Antimicrobial activity of extracts and some compounds from Calea platylepis. Fitoterapia. 2004;75(5):514-519.

9. do Nascimento AM, Salvador MJ, Candido RC, de Albuquerque S, de Oliveira DC. Trypanocidal and antifungal activities of p-hydroxyacetophenone derivatives from Calea uniflora (Heliantheae, Asteraceae). J Pharm Pharmacol. 2004;56(5):663-669.

10. Matsuura N, Yamada M, Suzuki H, et al. Inhibition of preadipocyte differentiation by germacranolides from Calea urticifolia in 3T3-L1 cells. Biosci Biotechnol Biochem. 2005;69(12):2470-2474.

11. Ribeiro VL, dos Santos JC, Martins JR, et al. Acaricidal properties of the essential oil and precocene II obtained from Calea serrata (Asteraceae) on the cattle tick Rhipicephalus (Boophilus) microplus (Acari: Ixodidae). Vet Parasitol. 2011;179(1-3):195-198.

12. Wu H, Fronczek FR, Burandt CL Jr, Zjawiony JK. Antileishmanial Germacranolides from Calea zacatechichi. Planta Med. 2011;77(7): 749-753.

13. Bork PM, Schmitz ML, Kuhnt M, Escher C, Heinrich M. Sesquiterpene lactone containing Mexican Indian medicinal plants and pure sesquiterpene lactones as potent inhibitors of transcription factor NF-kappaB. FEBS Lett. 1997;402(1):85-90.

14. Rivero A, Quintana J, Eiroa JL, et al. Potent induction of apoptosis by germacranolide sesquiterpene lactones on human myeloid leukemia cells. Eur J Pharmacol. 2003;482(1-3):77-84.

15. Nakagawa $Y$, Iinuma $M$, Matsuura $N$, et al. A potent apoptosis-inducing activity of a sesquiterpene lactone, arucanolide, in HL60 cells: a crucial role of apoptosis-inducing factor. J Pharmacol Sci. 2005;97(2):242-252.

16. Skehan P, Storeng R, Scudiero D, et al. New colorimetric cytotoxicity assay for anticancer-drug screening. J Natl Cancer Inst. 1990;82(13): $1107-1112$.

17. Holbeck SL. Update on NCI in vitro drug screen utilities. Eur J Cancer. 2004;40(6):785-793.

18. Shoemaker RH. The NCI60 human tumour cell line anticancer drug screen. Nat Rev Cancer. 2006;6(10):813-823.

19. Fouche G, Cragg GM, Pillay P, Kolesnikova N, Maharaj VJ, Senabe J. In vitro anticancer screening of South African plants. J Ethnopharmacol. 2008;119(3):455-461.

20. Longato GB, Rizzo LY, Sousa IM, et al. In vitro and in vivo anticancer activity of extracts, fractions, and eupomatenoid-5 obtained from Piper regnellii leaves. Planta Med. 2011;77(13):1482-1488.

21. Lapa AJ, Souccar C, Lima-Landman MTR, Castro MSA, Lima TCM. Métodos de Avaliação da Atividade Farmacológica de Plantas Medicinais. Porto Alegre: Metrópole; 2003. Portuguese.

22. Litchfield JT Jr, Wilcoxson F. A simplified method of evaluating dose-effect experiments. J Pharmacol Exp Ther. 1949;96(2):99-113.

23. Sacoman JL, Monteiro KM, Possenti A, Figueira GM, Foglio MA, Carvalho JE. Cytotoxicity and antitumoral activity of dichloromethane extract and its fractions from Pothomorphe umbellata. Braz J Med Biol Res. 2008;41(5):411-415.

24. Rates SM. Plants as source of drugs. Toxicon. 2001;39(5):603-613.

25. Jemal A, Siegel R, Ward E, Hao Y, Xu J, Thun MJ. Cancer Statistics, 2009. CA Cancer J Clin. 2009;59(4):225-249.

26. Smith JA, Ngo H, Martin MC, Wolf JK. An evaluation of cytotoxicity of the taxane and platinum agents combination treatment in a panel of human ovarian carcinoma cell lines. Gynecol Oncol. 2005;98(1):141-145.

27. Lobo C, Ruiz-Bellido MA, Aledo JC, Márquez J, Núñez De Castro I, Alonso FJ. Inhibition of glutaminase expression by antisense mRNA decreases growth and tumourigenicity of tumour cells. Biochem J. 2000;348 Pt 2:257-261. 
28. Fecchio D, Sirois P, Russo M, Jancar S. Studies on inflammatory response induced by Ehrlich tumor in mice peritoneal cavity. Inflammation. 1990;14(1):125-131.

29. Vendramini-Costa DB, de Castro IB, Ruiz AL, Marquissolo C, Pilli RA, de Carvalho JE. Effect of goniothalamin on the development of Ehrlich solid tumor in mice. Bioorg Med Chem. 2010;18(18):6742-6747.
30. Hanahan D, Weinberg RA. Hallmarks of cancer: the next generation. Cell. 2011;144(5):646-674.

Journal of Experimental Pharmacology

Dovepress

\section{Publish your work in this journal}

The Journal of Experimental Pharmacology is an international, peerreviewed, open access journal publishing original research, reports, reviews and commentaries on all areas of laboratory and experimental pharmacology. The manuscript management system is completely online and includes a very quick and fair peer-review system.

Visit http://www.dovepress.com/testimonials.php to read real quotes from published authors. 